\title{
System-level Insights into the Adaptation of Domestic Dairy Buffalo to Chronic
} 2

\section{Heat Stress}

Zhaobing Gu ${ }^{1}$, Shoukun Tang ${ }^{2}$, Xianhai Fu ${ }^{2}$, Chuanbin Liu ${ }^{2}$, Huaming Mao*,1,2 4

1 Faculty of Animal Science and Technology, Yunnan Agricultural University, Kunming 650201, China

2 Bureau of animal husbandry and veterinary medicine, mangshi 678499, China.

3 Yunnan Provincial Key Laboratory of Animal Nutrition and Feed Science, Kunming 650201, China;

\section{* Corresponding authors:maohm@,vip.sina.com}

(1)

Abbreviations: CATHL2 (LL-37), cathelicidin-2; CP, ceruloplasmin; GPX3, glutathione peroxidase 3; Hb, hemoglobin; HBA1, hemoglobin subunit alpha 1; HCT, hematocrit; HS, heat stress; LFQ, label-free quantification; LPL, Lipase; MCHC, mean corpuscular hemoglobin concentration; $\mathrm{MCH}$, mean corpuscular hemoglobin; $\mathrm{MCV}$, mean corpuscular volume; PLT, platelet hematocrit; PRM, parallel reaction monitoring; RBC, red blood cell count; ROS, reactive oxygen species; RR, Respiration rates; SRM/MRM, Single or multiple reaction monitoring; THI, Temperature-humidity index; WBC, white blood cell count; TN, thermal-neutral conditions 

1 4 36

Abstract: Chronic heat stress (HS), aggravated by global warming, reduces the production efficiency of the buffalo dairy industry. Here, we conducted a proteomic analysis to investigate the adaptation strategies used by buffalo in response to heat stress. Seventeen differentially abundant proteins with known functions were detected using label-free quantification (LFQ), and five of these differentially expressed proteins were validated with parallel reaction monitoring (PRM). These five proteins were associated with various aspects of heat stress, including decreased heat production, increased blood oxygen delivery, and enhanced natural disease resistance. Lipase (LPL), glutathione peroxidase 3 (GPX3), cathelicidin-2 (CATHL2, LL-37), ceruloplasmin (CP), and hemoglobin subunit alpha 1 (HBA1) were shown to play cooperative roles in the tolerance of chronic HS in dairy buffalo. We found that high levels of HBA1 increased blood oxygen transport capacity. Our results increase our understanding of the adaptation of dairy buffalo to chronic heat stress.

Keywords: chronic heat stress; dairy buffaloes; proteomics; adaptation mechanisms (1) 30 32 33 35 


\section{Introduction}

In 2016, the global population of domestic buffalo (Bubalus bubalis) was $\sim 199.0$ million; about $99 \%$ of these buffalo inhabit tropical and subtropical regions [1]. At present, the mean daily maximum temperature across the regions where buffalo are raised is $19.7-41.2^{\circ} \mathrm{C}$, but it is predicted that the daily maximum temperature in these regions will increase by $1-4.5^{\circ} \mathrm{C}$ over the next 50 years [2]. Although buffalo are well adapted to hot climates $[3,4]$, they show signs of thermal discomfort, such as low milk yield and poor reproductive performance, at temperatures exceeding $25^{\circ} \mathrm{C}$ [5]. Indeed, the body temperatures of buffalo kept at $42.1^{\circ} \mathrm{C}$ for $2-3 \mathrm{~h}$ increased from $37.5-38.5^{\circ} \mathrm{C}$ to $41.1^{\circ} \mathrm{C}$, and the respiratory rates increased from 28.7 breaths $/ \mathrm{min}$ to $128 \mathrm{breaths} / \mathrm{min}$ [6]. At ambient temperatures of $29.4^{\circ} \mathrm{C}$ and $38.9^{\circ} \mathrm{C}$, nutrient intake and milk yield decreased $\sim 30.0 \%$ and $\sim 27.6 \%$, respectively $[7,8]$. In addition, buffalo have fewer sweat glands than do cattle, increasing heat sensitivity $[3,9,10]$. Thus, buffalo may be increasingly prone to heat stress as global warming progresses, threatening the buffalo dairy industry [11-13].

Chronic heat stress (HS) occurs after prolonged exposure to elevated ambient temperatures and high humidity, when the animal is unable to dissipate excessive heat load to the surrounding environment [14]. HS stimulates the excessive accumulation of reactive oxygen species (ROS), which triggers the oxidative stress response [15-17]. High concentrations of ROS limit energy production and utilization in heat-stressed animals [18], negatively affecting animal growth, production, and reproductive performance [19-22]. To improve the production efficiency of dairy buffalo, it is 
59

60

61

62

important to investigate the mechanisms underlying thermal tolerance using protein biomarkers.

Proteomics have been widely used to assess the ability of livestock to adapt to temperature increases [23]. Specifically, label-free quantification (LFQ) is a highresolution method based on mass spectrometry, which determines the relative amounts of protein among two or more biological samples without the use of stable isotopes [24]. LFQ extracts peptide signals on the MS1 level, and thus uncouples the quantification process from the identification process [25]. Single and multiple reaction monitoring (SRM/MRM) methods have been widely used for protein absolute quantification due to their high sensitivity, accuracy, and repeatability. Parallel reaction monitoring (PRM) is high-resolution ion monitoring technique (5-6 orders of magnitude), which detects all product ions in parallel in a high-precision mass spectrometer [26]. The principle of this technique is similar to SRM/MRM, but PRM is more convenient and more selective than SRM/MRM [27]. PRM is thus most suitable for the absolute quantification of multiple proteins in a complex sample with an attomole-level of detection.

For livestock, blood sampling is convenient, and blood biomarkers are useful indicators of the physiological state of the animal [28]. We thus hypothesized that some serum proteins would be important for HS tolerance in buffalo. To address this hypothesis, we aimed to detect targeted serum proteins closely related to HS with LFQ, and then perform an absolute quantification of these proteins with PRM. In this way, we aimed to identify candidate protein biomarkers of chronic HS to improve the thermal tolerance of dairy buffalo. 


\section{Results}

The average THI values were 75.76 and 54.26 under the HS and TN conditions, respectively $(p<0.001)$. The body temperatures of the HS and TN buffalo $\left(38.24^{\circ} \mathrm{C}\right.$ and $38.16^{\circ} \mathrm{C}$, respectively) were not significantly different $(p>0.05)$. However, the RR of the HS buffalo (32.5 breaths/min) was significantly greater than that of the TN buffalo (19.0 breaths/min; $p<0.001)$.

\subsection{Identification of proteins related to HS adaptation}

Using LFQ, 344 low-abundance proteins were identified in the serum samples. Of these, our LFQ results indicated that 17 were differentially expressed in HS buffalo as compared to the TN buffalo (Table 1). Our volcano plot indicated that four of these proteins were more abundant in HS buffalo, while 13 were less abundant (Figure 1).

Our hierarchical clustering analysis indicated that the 17 differentially abundant proteins grouped well by function: proteins similar to RETN formed one cluster, and the other cluster comprised CP (L8I5R0 and D2U6Z5), HBA1, and LL-37. L8I5R0 and D2U6Z5, both representing CP, were obviously closely clustered (Figure 2). Interestingly, four of the differentially abundant proteins identified by both LFQ and PRM were enzymes. Of these, CP (L8I5R0, D2U6Z5), HBA1 (Q9TSN7) and LL-37 (A0A0A7V3V9) were significantly more abundant in HS buffalo as compared to TN buffalo ( $p<0.05$ for all): HBA1 (3.76-fold increase), CP (1.50-fold increase) and LL37 (1.84-fold increase) (Figure 3). The remaining enzymes, LPL and GPX3, were significantly less abundant in HS buffalo as compared to TN buffalo (0.59-fold and 0.35-fold decrease, respectively; $p<0.05$; Table 1 ). 


\subsection{GO, KEGG, and protein-protein interaction}

We identified three groups of GO terms that were highly enriched in the 17 differentially expressed proteins identified by LFQ (Table 2). One set of enriched GO terms was associated with redox reactions, lipase activity, hydrolysis, and oxygen transport, while a second set was associated with correct protein folding or the degradation of mis-folded proteins (ubiquitin protein ligase binding, heat shock protein binding, and unfolded protein binding). The third set of enriched GO terms were associated with nitric-oxide synthase regulator activity (i.e., vasodilatation), ferroxidase activity, and oxygen binding.

In parallel studies, we analyzed the correlations among the 17 differentially abundant proteins identified by LFQ, and quantified the metabolites [29]. Only four proteins could be mapped to KEGG metabolic pathways: GPX3, CP, CD14, and LL-37. GPX3 and CP produce glutamic acid; similar amounts of glutamic acid were produced by the HS buffalo $(34.2 \mu \mathrm{M})$ and the TN buffalo $(26.8 \mu \mathrm{M} ; p>0.05)$. CD14 and LL37 produce acetylcholine; significantly more acetylcholine was produced by the HS buffalo $(0.19 \mathrm{nM})$ than the TN buffalo $(0.16 \mathrm{nM} ; p<0.001)$. GPX3 was associated with the glutathione metabolism pathway; $\mathrm{CP}$ was associated with the porphyrin metabolism pathway; CD14 was associated with the regulation of the actin cytoskeleton; and LL37 was associated with salivary secretions.

We analyzed the PPI networks of 16 of the 17 differentially abundant proteins identified by LFQ. CD14, CPN1, HBA1, HAVCR1, CHST4, THBS4, SPARCL1 and PLA1A were not included in the network (Figure 4). This network had eight edges, 
with an average node degree of 1 , and an average local clustering coefficient of 0.479 .

The expected number of edges was 2 , giving a network enrichment $p$-value of 0.000221 . In particular, two of the PPIs (LPL and RETN; CP and GPX3) function synergistically to increase thermal tolerance in HS buffalo.

\subsection{Validation of $L F Q$ results with $P R M$}

We used PRM to validate the differential abundance of five proteins: CP (L8I5R0 and D2U6Z5), HBA1, LPL, LL-37, and GPX3 (Table 1). Three of these proteins (HBA1, CP, and LL-37) were identified as significantly more abundant in HS buffalo as compared to TN buffalo by both LFQ and PRM (Figure 3). However, although LFQ analysis identified GPX3 as significantly more abundant in HS buffalo, PRM did not identify a significant difference in GPX3 abundance between HS and TN buffalo $(p=0.363)$.

\subsection{Biochemical blood analysis}

HS buffalo had significantly lower levels of MCHC $(p<0.05)$ and $\mathrm{MCH}(p<0.01)$ than did TN buffalo, and significantly higher levels of HCT $(p<0.01)$ and MCV $(p<$ 0.01; Figure 5). Although HS buffalo had slightly higher levels of RBC, Hb, and PLT, as well as slightly lower levels of WBC, these differences were not significant (Figure $5)$.

\section{Discussion}

No significant differences in body temperature were detected between the HS and TN buffalo, indicating that buffalo can maintain normal body temperatures under HS conditions. However, HS buffalo breathed significantly faster than TN buffalo $(p<$ 
0.001), improving respiratory evaporative heat loss. In addition to physiological regulation, animals cope with high heat and high humidity primarily through biochemical strategies [30]. In particular, we here identified 17 proteins that were differentially abundant in HS buffalo as compared to TN buffalo. Several of these proteins were associated with functions related to HS. For example, HBA1, which was significantly more abundant in HS buffalo, is involved in heme and iron binding, and transports oxygen from the lungs to various inner organs and peripheral tissues [31]. CP was significantly more abundant in HS buffalo, which plays an important role in iron transport and protects cellular lipids from iron-dependent lipid peroxidation [3234]. Heat-stressed animals have poor appetites and low nutrient intake, requiring efficient energy usage [35]. Under HS conditions, triglycerides are hydrolyzed by LPL to free fatty acids for supplemental energy [36]. However, triglyceride degradation decreases fatty acid oxidation, resulting in reduced ATP production [37]. This was consistent with our results, as the HS buffalo had significantly higher LPL levels than the TN buffalo.

Under normal condition, $\mathrm{ROS}\left(\right.$ e.g., $\mathrm{H}_{2} \mathrm{O}_{2}$ and $\mathrm{O}^{2 \cdot-}$ ) play important roles as signal molecules [38]. However, HS triggers excessive ROS accumulation, causing damage to biological macromolecules [39]. As a well-known redox protein and antioxidant enzyme, GPX3 protects cells from oxidative stress by decomposing $\mathrm{H}_{2} \mathrm{O}_{2}$ [40,41]. LFQ abundance analysis indicated that HS buffalo had significantly lower levels of serum GPX3 than did TN buffalo, suggesting that the HS buffalo were experiencing HS [42]. Consistent with this result, previous studies of livestock (e.g., finishing broilers, cattle, 
and dairy cows) reported that HS decreased GPX3 activity. [43-46]. It is worth noting that, although PRM analysis indicated that mean GPX3 levels in HS buffalo were lower than those in TN buffalo, these differences were not significant. This suggested that HS buffalo maintain normal GPX3 levels to protect cell membranes from oxidative damage. In addition, $\mathrm{H}_{2} \mathrm{O}_{2}$ inhibits protein refolding and leads to protein denaturation, which is detrimental to cellular structure and function. [47]. Indeed, several GO terms significantly enriched in the differentially abundant proteins are known to promote correct protein folding and degrade mis-folded proteins (i.e., ubiquitin protein ligase binding, heat shock protein binding, and unfolded protein binding). This might imply that buffalo use posttranslational protein processing to handle HS.

Chronic HS impairs immune function in animals, and also increases susceptibility to infection [48]. LL-37, a small cationic antimicrobial peptide produced in the epithelial cells, disrupts the activity of gram-negative bacteria by damaging and destroying bacterial membranes $[49,50]$. LL-37 plays key roles in inflammatory response regulation and immune mediator induction [51,52]. In heat-stressed mice, LL37 production was suppressed by the nicotinic acetylcholine system, increasing the susceptibility of the mice Staphylococcus aureus [53]. In HS buffalo, LL-37 was significantly more abundant than in TN buffalo (based on both LFQ and PRM), suggesting that the HS buffalo might also be more susceptible to infection. As LL-37 is important for the immune and inflammatory response [54,55]. it is possible that the higher LL-37 serum levels seen here in HS buffalo might compensate for the relatively low GPX3 levels. 
The differential abundant proteins in HS buffalo as compared to the TN buffalo

192

193

194

195 were also significantly enriched in the GO term nitric-oxide synthase regulator activity, which is associated with peripheral vasodilatation [56]. HS buffalo deliver more oxygen per unit volume of blood than cattle [57]. In vasodilation, blood flow to the body surface is increased to enhance heat dissipation, and oxygen transport to internal organs is improved. This was consistent with the high levels of HBA1 and RBC detected in the HS buffalo.

We were unable to identify metabolic (KEGG) pathways enriched in most of the 17 differentially abundant proteins identified by LFQ. However, we successfully mapped four proteins (GPX3, CP, CD14 and LL-37) and their corresponding metabolites to metabolic pathways. As a major neurotransmitter in animals, acetylcholine participates in homoeothermic thermoregulation [58]. Acetylcholine is also known to regulate glutamic acid release, and glutamic acid generates glutamate via pyroglutamic acid [59]. Glutamate and GPX produce glutathione via the glutathione metabolism pathway [60], and GPX3 and glutathione protect the cell from heat injury [61]. Glutamic acid, along with $\mathrm{CP}$, is also involved in the porphyrin metabolism pathway, which increases HBA1 levels to improve oxygen transport in HS animals. LL37 and acetylcholine were mapped to the salivary secretion pathway. As buffalo, which have few sweat glands [3], dissipate only $12 \%$ of their excess heat through skin evaporation [9]; salivary secretions have been shown to help decrease body temperature $[62,63]$.

Under HS conditions, high levels of hemoglobin lead to increased oxygen delivery 
213 [64]. Based on these pathways and our results, we propose a model of HS adaptation in 214 dairy buffalo (Figure 6): an increase in HBA1 abundance to eliminate ROS and 215 maintain normal oxygen supply, and an increase in LL-37 abundance to enhance host 216 disease resistance. PPI networks provide collaborative working modes for 217 physiological and biological processes at the system-level [65]. We found that most of 218 the 17 differentially abundant proteins in HS buffalo as compared to TN buffalo were 219 linked in the H. sapiens database (Fig. 4). CD14, CHST4, HBA1, SPARCL1, CPN1, THBS4, SPARCL1, and PLA1A were not linked to each other, possible because these proteins have dissimilar functions.

It is well known that $\mathrm{Hb}$ and $\mathrm{CP}$ play a collaborative role in oxygen delivery, as $\mathrm{CP}$ oxidizes $\mathrm{Fe} 2+$ to $\mathrm{Fe} 3+$ without releasing $\mathrm{ROS}$ [66]. Indeed, we observed a concomitant increase in $\mathrm{Hb}$ and $\mathrm{CP}$ in $\mathrm{HS}$ buffalo, consistent with a previous study [54]. However, to date, no biological interaction networks have shown a direct relationship between these proteins, although $\mathrm{CP}$ was shown to have an inverse linear relationship 227 with soluble transferrin receptor levels [67]. Therefore, we speculated that $\mathrm{Hb}$ might 228 have an indirect relationship with CP. That is, these proteins were not linked in the PPI network, but $\mathrm{Hb}$ and $\mathrm{CP}$ are functionally similar, and their serum levels increased simultaneously. Previous studies have reported that RETN and LPL are important for 231 glucose and lipoprotein metabolism [68], and the PPI between RETN and LPL 232 indicated that the metabolic profiles of glucose and lipoprotein were altered by HS. Moreover, the enzymatic oxidant GPX3 and the nonenzymatic antioxidant CP protect the cell from damage due to oxidative stress [69]. 
isoforms of 14-3-3 proteins, which act as molecular chaperones [70]. YWHAZ

negatively regulates cell death, and YWHAE facilitates the movement of phosphorylated HSF1 from the nucleus to the cytoplasm, increasing cell thermotolerance. The three 14-3-3 proteins were downregulated in the HS buffalo, suggesting that other proteins may perform these biological functions under HS.

Under HS, homoeothermic animals facilitate heat dissipation by increasing body temperature, respiratory rate, and blood flow to the peripheral tissues $[71,72]$. The demands on the cardiovascular system also increase with HS, as does arterial blood pressure, causing internal tissues and organs to compete with peripheral areas for blood supply $[73,74]$. Eventually, low blood flow volume may result in the hypoxia of the internal organs [75]. Indeed, body temperature and blood flow may be closely associated [76]: it was shown that blood flow to internal organs, such as the reproductive organs, decreased $20-40 \%$ in heat-stressed rabbits [77]. compared to TN cattle [79]. Here, the RBC of the HS buffalo was not significantly different from that of the TN buffalo. This might indicate HS buffalo protect RBCs from heat injury. $\mathrm{Hb}$ is associated with the delivery of oxygen from the lungs to various other 253 tissues [80]. An increase in serum $\mathrm{Hb}$ may compensate for a decrease in RBC and low $\mathrm{MCV}$, enabling the maintenance of normal oxygen supply under chronic HS. It may be that high levels of serum $\mathrm{Hb}$ protect the red blood cells from oxidative stress $[81,82]$. 
257

258

259

260

261

262

263

264

265

266

267

268

269

270

271

272

273

274

275

276

277

278

including sheep, goats, piglets, ruminants (Holsteins, Jerseys, and Zebus), and tilapia [83-88].

$\mathrm{Hb}$ increases may be due to low oxygen pressure and saturation, or to an improved resistance to ROS [89]. In contrast, cooling increased blood $\mathrm{Hb}$ concentrations in HS Murrah buffalo [90]. Thus, high Hb levels may alleviate the deleterious effect of HS and hypoxia. However, one study showed that HS decreased blood Hb concentration as compared to normal temperatures [91]. which may be because the acute HS animals in that study were exposed to extremely high temperatures $\left(40 \pm 2^{\circ} \mathrm{C}\right)$. Here, the chronic HS buffalo had higher serum $\mathrm{Hb}$ as compared to TN buffalo. The HS buffalo also had significantly higher concentrations of HBA1 than the TN buffalo, indicating that high HBA1 concentrations may alleviate the tissue and organ hypoxia caused by an increased respiratory rate. Indeed, it has been shown that HBA1 plays an important role in increasing blood flow to peripheral tissues. HS buffalo also had significantly lower levels of $\mathrm{MCHC}$ and $\mathrm{MCH}$, as well as significantly higher levels of $\mathrm{HCT}$ and MCV. This might indicate that dairy buffalo under chronic HS maintain a normal oxygen supply by modulating crucial blood parameters.

HS animals decrease nutrient intake, leading to a negative energy balance7. Because fatty acid oxidation produces more heat (146 ATP) than does carbohydrate (38 ATP), heat-stressed animals decrease fatty acid oxidation [7,92]. LPL is synthesized at the surface of the vascular endothelium and released into the blood. LPL hydrolyzes circulating triacylglycerides to free fatty acids, promoting fat synthesis while decreasing the production of ATP and heat [93]. In addition to decreasing heat 
279 production, fat deposition is beneficial under HS as fat insulates the body to decrease 280 solar radiant heat absorption [94]. Indeed, low levels of glycerol in the plasma of 281 ruminants were found in summer [95]. However, few studies have focused on serum 282 profiles of LPL abundance. LPL levels in pig adipose tissue increased in response to 283 mild HS [96]. as did adipogenesis in porcine adipocytes [97]. LPL activity increased in 284 the plasma and muscle of HS rats, but not in the white adipose tissue [98]. We found 285 that serum LPL abundance decreased in response to chronic HS. We thus speculated 286 that dairy buffalo, unlike monogastric animals, adapt to chronic HS by decreasing fatty 287 acid oxidation to reduce heat production. Based on the HS-related functions of LL-37 288 (physiological defense response), ceruloplasmin (copper ion binding and ferroxidase 289 activity), and HBA1 (oxygen delivery), as well as the associated metabolites, we 290 proposed a model of the anti-HS adaptive mechanisms used by dairy buffalo to cope 291 with chronic HS (Figure 6).

\section{Materials and Methods}

\subsection{Animals}

Animals were treated according to the strictures of the Animal Welfare Act, as issued by Animal Ethics Committee of Yunnan Province, China in 2007. All animals were loose housed, and provided with fresh drinking water ad libitum. Animals were

297 fed mixed rations (80\% whole-plant corn silage ad libitum, 12.5\% feed concentrate, and $7.5 \%$ corn protein powder).

The temperature-humidity index (THI) was calculated based on air temperature 
301

302

animals under HS, THI is widely used to assess the degree of HS [99]. THI values $\geq 72$ have been shown to affect dairy cattle [100]. In Dehong, Yunnan province, China $\left(24.43^{\circ} \mathrm{N}, 98.57^{\circ} \mathrm{E}\right.$; altitude: $\left.870 \mathrm{~m}\right)$, average THI has been $\geq 72$ between June and August 2005-2015, based on meteorological data. Therefore, six multiparous Nili-Ravi $\times$ Murrah $\times$ local crossbred female buffaloes (group HS; daily average milk yield 4.5 $\mathrm{kg}$ ) with similar lactation were used for the heat stress experiment at this site between July 20 and August 4, 2016 (average THI 75.76). We tested another six dairy buffaloes (daily average milk yield $6.1 \mathrm{~kg}$ ) under thermal-neutral conditions (group TN) between January 3 and January 18, 2017 (average THI 54.26).

\subsection{Environmental and physiological parameters}

Temperature and humidity loggers $\left( \pm 0.2^{\circ} \mathrm{C}\right.$; Testo $\left.175 \mathrm{H} 1\right)$, placed $2.0 \mathrm{~m}$ above the floor of the bedding area, recorded ambient temperature and relative humidity at $30 \mathrm{~min}$ intervals. We used these figures to calculate THI: THI $=(1.8 \times \mathrm{T}+32)-(0.55-0.0055$ $\times \mathrm{RH}) \times(1.8 \times \mathrm{T}-26)[89]$, where $\mathrm{T}$ was the ambient temperature $\left({ }^{\circ} \mathrm{C}\right)$ and $\mathrm{RH}$ was the relative humidity $(\%)$.

Respiration rates (RR; breaths/min) were measured daily at 08:00, 13:00, and 18:00 h using a stopwatch. A waterproof micro-temperature sensor $\left( \pm 0.5^{\circ} \mathrm{C}\right.$; DS1922L, Wdsen Electronic Technology Co., Ltd), fixed in the slot of a T-shaped controlled internal drug release device (without progesterone; DEC International NZ Ltd), was placed in the vagina of each buffalo. This device recorded body temperature at $30 \mathrm{~min}$ intervals.

\subsection{Depletion of high-abundance proteins from the serum}


Blood samples were collected with vacutainer tubes via jugular venipuncture.

324

325

Each sample was centrifuged at $1400 \mathrm{~g}$ for $10 \mathrm{~min}$ to separate the serum. Serum samples were stored at $-80^{\circ} \mathrm{C}$. High-abundance proteins in the serum samples were depleted using affinity chromatographic columns (Agilent Multiple Affinity Removal LC Columns). The low-abundance proteins in the serum samples were isolated by first performing an ultrafiltration concentration, then adding one double volume of SDT buffer (4\% SDS, $100 \mathrm{mM}$ Tris-HCl, and $1 \mathrm{mM} \mathrm{DTT;} \mathrm{pH}$ 7.6) to the concentrated sample. The resultant mixture was then incubated in a boiling water bath for $15 \mathrm{~min}$. The mixture was then centrifuged at $14000 \mathrm{~g}$ for $20 \mathrm{~min}$, and the supernatant was removed. We then added $20 \mu \mathrm{g}$ of the supernatant to $5 \times$ loading buffer $(10 \%$ SDS, $0.5 \%$ bromophenol blue, 50\% glycerol, $500 \mathrm{mM}$ DTT, and $250 \mathrm{mM}$ TrisHCl; pH 6.8). This mixture was incubated in a $90^{\circ} \mathrm{C}$ water bath for $5 \mathrm{~min}$, and then analyzed using $12.5 \%$ SDS-PAGE (constant $14 \mathrm{~mA}$ current for $90 \mathrm{~min}$ ) with Coomassie blue staining.

\subsection{Filter-added sample preparation protein digestion}

Trypsin protein digestion was performed using the filter-aided sample preparation (FASP) procedure described previously [101]. In brief, serum samples were lysed, and proteins were extracted using SDT buffer. Proteins were quantified with BCA Protein Assay Kits (Bio-Rad). We then analyzed $20 \mu \mathrm{g}$ of each extracted protein sample with SDS-PAGE. Next, $100 \mu \mathrm{g}$ of extracted protein was dissolved in DTT (to generate a final concentration of $10 \mathrm{mM}$ ) in a $90^{\circ} \mathrm{C}$ water bath for $15 \mathrm{~min}$, and then cooled to room temperature. Small molecules and detergent were extracted using $10 \mathrm{kD}$ ultrafiltration with $200 \mu \mathrm{L}$ UA buffer (8 M Urea and $150 \mathrm{mM}$ Tris-HCl; $\mathrm{pH}$ 8.0). The mixture was 
345

centrifuged four times at $14,000 \mathrm{~g}$ for $30 \mathrm{~min}$, and the filtrate was discarded. We then added 100 IAA buffer (50 mM IAA in UA buffer) to the concentrate. Prior to centrifugation, this mixture was shaken at $600 \mathrm{rpm}$ for $1 \mathrm{~min}$, and then incubated for 30 min in the dark. After incubation, the mixture was centrifuged at $14000 \mathrm{~g}$ for $20 \mathrm{~min}$. The filter was washed three times with $100 \mu \mathrm{L}$ of UA buffer and centrifuged at 14000 g for $20 \mathrm{~min}$. Then, the filter was washed twice with $100 \mu \mathrm{L}$ of $50 \mathrm{mM} \mathrm{NH} 4 \mathrm{HCO} 3$ buffer. Finally, the protein suspension was added to $40 \mu \mathrm{L}$ of NH4HCO3 buffer $(2 \mu \mathrm{g}$ Lys-C) and incubated in a $37^{\circ} \mathrm{C}$ water bath for $4 \mathrm{~h}$. We added $2 \mu \mathrm{g}$ trypsin to the protein mixture, and then incubated the mixture in a $37^{\circ} \mathrm{C}$ water bath for $16 \mathrm{~h}$. After incubation, the protein mixture was transferred to a fresh reaction tube, and centrifuged at $14000 \mathrm{~g}$ for $15 \mathrm{~min}$. Finally, the filter was washed with $40 \mu \mathrm{L}$ of $50 \mathrm{mM}$ NH4HCO3 buffer, and centrifuged at $14000 \mathrm{~g}$ for $30 \mathrm{~min}$. The filtrate was collected and desalinated with a C18 Cartridge (Empore SPE Cartridges C18 [standard density], Sigma; bed inner diameter $7 \mathrm{~mm}$; volume $3 \mathrm{ml}$ ). Desalted samples were freeze-dried, and peptide levels were determined at $\mathrm{OD} 280$. Peptide samples were then stored at $-80^{\circ} \mathrm{C}$.

\subsection{LFQ with LC-MS/MS analysis}

We performed relative LFQ with LC-MS/MS. LC-MS/MS was performed using a Q-Ex active mass spectrometer (Thermo Scientific) coupled to an Easy nLC 1200 (Proxeon Biosystems, now Thermo Fisher Scientific) with an analysis time of $60 \mathrm{~min}$. First, peptides were loaded onto a reverse phase trap column (Thermo Scientific Acclaim PepMap100; $100 \mu \mathrm{m} \times 2 \mathrm{~cm}$; nanoViper C18) connected to a C18-reversed phase analytical column (Thermo Scientific Easy Column; $10 \mathrm{~cm}$ long, $75 \mu \mathrm{m}$ inner 
diameter, $3 \mu \mathrm{m}$ resin) in buffer A ( $0.1 \%$ formic acid). Peptides were separated using a linear gradient of buffer B ( $84 \%$ acetonitrile and $0.1 \%$ formic acid) at a flow rate of 300 $\mathrm{nl} / \mathrm{min}$, controlled by an IntelliFlow technology. The linear gradient in the trap column was as follows: 0-35\% solution B from 0-50min; 35-100\% solution B from 50-55min; 40-100\% solution B from 55-60min; and hold at 100\% solution B.

MS raw data for all samples were combined and searched using MaxQuant v1.3.0.5 [102], which uses the Andromeda search engine against the Bovinae Uniprot database [103]. The precursor mass tolerance was set to $20 \mathrm{ppm}$ for the first Andromeda search, and to $6 \mathrm{ppm}$ for the main search. Carbamidomethylation (C) was considered a fixed modification, while oxidation (M) and acetylation (of the protein N-terminus) were considered variable modifications. We eliminated all peptide and protein identifications where the false discovery rate (FDR) was $>0.01$ against the reversedsequence database.

We used the MaxLFQ approach in MaxQuant for label-free quantification [104], enabling 'match between runs' with a retention time window of $2 \mathrm{~min}$, and setting the LFQ minimum ratio count to 1 . Using the relative abundance of proteins in TN buffalo as a reference, we identified HS-buffalo proteins as significantly differentially expressed if the HS protein was identified in at least two of three replicates with a fold change $>1.5$ and a $p<0.05$. We used volcano plots to visualize the differentially expressed proteins. We then performed a hierarchical clustering analysis of the proteins differentially expressed between the HS and TN buffalo using the log2-transformed expression values and a cutoff of $p<0.05$ in Treeview (Java Runtime Environment) 
389

390

391

392

393

394

395

[105].

\subsection{Absolute quantification of targeted proteins with PRM}

The Easy nLC 1200 (Thermo Scientific) was used for chromatographic separation.

First, peptides were separated with a binary solvent system consisting of $0.1 \%$ formic acid (solvent A) and $0.1 \%$ formic acid acetonitrile (84\% acetonitrile) (solvent B). We used $95 \%$ solvent $\mathrm{A}$ as the equilibrium liquid for the analytical column (ThermoScientific EASY column). We added 20 fmol of a standard peptide to $2 \mu \mathrm{g}$ of the separated peptides. The peptide mixture was then separated at a flow rate of 250 $\mathrm{nl} / \mathrm{min}$, with a linear gradient in the trap column (5-23\% solution B from 0-42 min; $23-40 \%$ solution B from $42-50 \mathrm{~min} ; 40-100 \%$ solution B from 50-60 min; and hold at $100 \%$ solution B).

We only selected proteins for PRM validation that were significantly more abundant and closely associated with heat stress adaptation. We examined the peptides eluted by the nano-high-performance LC using PRM positive ion mass spectrometry on a Q-Ex active HF mass spectrometer system (Thermo Scientific). MS spectra were acquired in the $\mathrm{m} / \mathrm{z}$ range $300-1800$, with an $R$ of 60000 at $\mathrm{m} / \mathrm{z} 200$. Automatic gain control (AGC) was set to 3e6, with a max injection time of $200 \mathrm{~ms}$. We then selected $20 \mathrm{PRM} / \mathrm{MS} 2$ scans for higher-energy collisional dissociation experiments that conformed to the following parameters: 1.6 Th isolation window; $R$ of 30,000 at $\mathrm{m} / \mathrm{z}$ 200; 3e6 AGC; 120 ms maximum injection time; MS2 higher-energy collisionally activated dissociation (HCD); and a normalized collision energy of 27.

We analyzed the PRM raw data from the 12 HS and TN samples with Skyline 
411

412

413

414

415

v3.5.0 [106]. The peptide settings used for the Skyline import were consistent with the MaxQuant search parameters (i.e., enzyme set to trypsin; max missed cleavages set to 2). For each set of Skyline analyses, we selected two or three consecutive high-intensity peptides for import into Skyline. Skyline was used to determine the number of targeted proteins, the sequences of the targeted peptides, the charges of the parent ions, and the peak areas. Total peak areas were calibrated against internal standard peptides, heavy isotopes (absolute quantification) [94]. Based on these total peak areas, we quantified each target peptide.

\subsection{Bioinformatics analysis}

We identified protein sequences homologous to those of the selected differentially expressed proteins with the NCBI BLAST+ client (ncbi-blast-2.2.28+-win32.exe) and InterProScan $[107,108]$. We then annotated protein sequences using gene ontology (GO) terms with Blast2GO $[109,110]$. The GO annotation results were plotted with R scripts. Following annotation, the differentially expressed protein sequences were blasted against the Kyoto Encyclopedia of Genes and Genomes (KEGG) database (http://geneontology.org/) to identify KEGG orthology. Differentially expressed proteins were subsequently mapped to KEGG pathways [111].

Finally, we constructed a functional protein interaction network for our differentially expressed proteins using STRING (https://string-db.org/), searching by multiple protein names. As few protein-protein interactions (PPI) are yet available in the Bos taurus database of STRING, we searched for these interactions in the Homo sapiens database instead. 
433

434

435

436

437

438

439

440

441

442

443

444

\subsection{Biochemical parameters}

We measured hemoglobin level ( $\mathrm{Hb}$ ), red blood cell count (RBC), white blood cell count (WBC), hematocrit (HCT), mean corpuscular hemoglobin concentration (MCHC), mean corpuscular hemoglobin (MCH), platelet hematocrit (PLT), and mean corpuscular volume (MCV) in the whole blood samples using a fully automated biochemical analyzer (Sysmex XT-1800i) within $24 \mathrm{~h}$ of blood collection.

\section{Conclusions}

Our results indicated that, in buffalo, pathways associated with oxidationreduction, hydrolysis, protein-mis-folding repair, and oxygen transport were activated by chronic HS, and that LPL, GPX3, LL-37, CP, and HBA1 played cooperative roles to mitigate the effects of chronic HS. Our results, along with our newly developed model, increase our understanding of the adaptation to heat stress in dairy buffalo. Our results will thus help to support the vigorous development of the buffalo dairy industry in tropical and subtropical regions.

\section{Acknowledgments:}

This study was supported by the National Science Foundation (31560626), Yunnan Agricultural Foundation Projects (2017FG001-008), and Yunnan Modern Agriculture Technology System of Dairy Industry. We thank the staff of Shanghai Applied Protein Technology for their technical assistance. Authors would also like to present thanks to the reviewers for their review. 
454

455

456

457

458

459

460

461

462

463

464

465

466

467

468

469

470

471

472

473

474

475

Figure 1. Quantitative proteomic comparison of serum samples of heat-stressed and normal-temperature buffalo. (a) Principal components analysis (PCA). (b) Volcano plot representation of moderated t-test analysis. Each point represents one protein. Fold change calculated based on the average of six samples. The horizontal bar represents a $q$-value cutoff of 0.01 . Significantly more abundant proteins in the heat-stress buffalo are shown in red; significantly less abundant proteins are shown in green. The significantly more abundant proteins were verified with parallel reaction monitoring analysis.

Figure 2. Hierarchical clustering of the proteins identified as differentially abundant in the heat-stressed buffalo as compared to the normal-temperature buffalo with label-free quantification analysis. Proteins are in rows; protein details are given in Table 1. Colors indicate level of abundance. HS1-HS6: heat-stress buffalo 1-6; TN1-6: normaltemperature buffalo 1-6. Asterisks indicate proteins that are significantly differently abundant between groups: ${ }^{*} p<0.05,{ }^{* *} p<0.01$.

Figure 3. Parallel reaction monitoring verification of five of the proteins indicated to be significantly differentially abundant by label-free quantification. HS: heat-stressed buffalo; TN: normal-temperature buffalo. Bars represent means $(n=6) \pm$ standard error. Asterisks indicate significant differences in abundance between the two groups: ${ }^{*} p<$ $0.05,{ }^{* *} p<0.01$. L8I5R0 and D2U6Z5 represent CP. For full protein names, please refer to Table 1.

Figure 4. Protein-protein interaction network including the proteins differentially abundant in heat-stressed buffalo as compared to normal-temperature buffalo. Blue 
476 edges indicate co-occurrence evidence; purple edges indicate experimental evidence;

477 yellow edges indicate text-mining evidence; light blue edges indicate database evidence;

478 and black edges indicate co-expression evidence. For full protein names, please refer 479 to Table 1.

480 Figure 5. Blood parameters of heat-stressed (black bars) and normal-temperature (gray 481 bars) buffalo. WBC: white blood cells $\left(\times 10^{9}\right)$; RBC: red blood cells $\left(\times 10^{12}\right)$; MCHC: 482 mean corpuscular hemoglobin concentration $(\mathrm{g} / \mathrm{L})$; $\mathrm{MCV}$ : mean corpuscular volume 483 (fL); Hb: hemoglobin (g/L); MCH: mean corpuscular volume (pg); PLT: platelet 484 hematocrit $\left(\times 10^{9}\right)$. Bars represent means $(n=6) \pm$ standard error. Asterisks indicate 485 significant differences in abundance between the two groups: ${ }^{*} p<0.05,{ }^{* * *} p<0.001$. 486 Figure 6. A proposed model of heat stress adaptation in dairy buffalo. Proteins and 487 metabolites in red or blue are significantly more or less abundant in heat-stressed 488 buffalo as compared to normal-temperature buffalo. 


\section{References}

\section{1. http://www.fao.org/faostat/en/\#data/QA}

2. Intergovernmental Panel on Climate Change in Climate Change: The Science of Climate Change, eds. Houghton, J. T.; Meira Filho, L. G.; Bruce, J.; Lee, H.; Callender, B. A.; Haites, E.; Harris, N.; Maskell, K. (Cambridge Univ. Press, Cambridge, U.K.) 1995.

3. Marai, I. F. M.; Haeeb, A. A. M. Buffalo's biological functions as affected by heat stress - A review. Livest Science. 2010, 127, 89-109.

4. Raval, J. K.; Patel, K. M.; Patel, J. M.; Mehta, H. D. Effect of climate on reproductive parameters of surati buffaloes reared under surati buffalo calf rearing project, Gujarat, Research in Environment and Life Sciences. 2014, 7, 197-200.

5. Chiappini, U.; Christiaens, J. P. A. Cooling in animal houses. 2nd report of working group on climatization of animal houses. CIGR, State University of Gent. Belgium. 1992, 82-97.

6. Zhang, C. X. Chinese Buffalo science, Guangxi Science and Technology Press. 2000, 11.

7. Wheelock, J. B., Rhoads, R. P.; Vanbaale, M. J.; Sanders, S.R.; Baumgard, L. H. Effects of heat stress on energetic metabolism in lactating holstein cows. J. Dairy. Sci. 2010, 93, 644-655.

8. Baumgard, L. H.; Rhoads, R. P. Effects of heat stress on postabsorptive metabolism and energetics. Annu. Rev. Anim. Biosci. 2013, 1, 311-337.

9. Aggarwal, A.; Upadhyay, R. C. Studies on evaporative heat loss from skin and pulmonary surfaces in male buffaloes exposed to solar radiations. Buffalo J. 1998, 2, 179-187. 
10. Chanda, T.; Debnath, G. K.; Khan, K. I.; Rahman M. M.; Chanda, G. C. Impact of heat stress on milk yield and composition in early lactation of Holstein Friesian crossbred cattle. Bang. J. Anim. Sci. 2017, 46, 192-197.

11. Renaudeau, D.; Collin, A.; Yahav, S.; de Basilio, V.; Gourdine J. L.; Collier, R. J. Adaptation to hot climate and strategies to alleviate heat stress in livestock production. Animal. 2012, 6, 707-728.

12. Ganaie, A. H.; Shanker, G.; Bumla, N. A.; Ghasura, R. S.; Mir, N. A.; Wani, S. A.; Dudhatra, G. B. Biochemical and physiological changes during thermal stress in bovines: a review. J. Vet. Sci. Technol. 2013, 4, 423-430.

13. Kapila, N.; Kishore, A.; Sodhi, M.; Sharma, A. K.; Mohanty, A. K.; Kumar, P.; Mukesh, M. Temporal changes in mRNA expression of heat shock protein genes in mammary epithelial cells of riverine buffalo in response to heat stress in vitro. International Journal of Animal Biotechnology. 2013, 3, 5-9.

14. Dunshea, F. R.; Leury, B. J.; Fahri, F.; Digiacomo, K.; Hung, A.; Chauhan, S.; Clarke, I. J.; Collier, R.; Little, S.; Baumgard, L.; Gaughan, J. B. Amelioration of thermal stress impacts in dairy cows. Anim. Prod. Sci. 2013, 53, 965-975.

15. Lord-Fontaine, S.; Averill-Bates, D. A. Heat shock inactivity cellular antioxidant defenses against hydrogen peroxide: protection by glucose. Free. Radic. Biol. Med. 2002, 32, 752-765.

16. Glombowsky, P.; Bottari, N. B.; Klauck, V.; Fávero, J. F.; Soldá, N. M.; Baldissera, M. D.; Perin, G.; Morsch, V. M.; Schetinger, M. R. C.; Stefani, L. M.; Da Silva, A. 
S. Oxidative stress in dairy cows seropositives for neospora caninum. Comp. Immunol. Microb. 2017, 54, 34.

17. Ghosh, C. P.; Kesh, S. S.; Tudu, N. K.; Datta, S. Heat Stress in Dairy Animals - Its Impact and Remedies: A Review. Int. J. App. Pure. Biosci. 2017, 5, 953-965.

18. Slimen, B.; Najar, T.; Ghram, A.; Abdrrabba, M. Heat stress effects on livestock: molecular, cellular and metabolic aspects, a review. J. Anim. Physiol. An. A. 2016, $100,401-412$.

19. Hozyen, H. F.; Ahmed, H. H.; Essawy, G. E. S.; Shalaby, S. I. A. Seasonal changes in some oxidant and antioxidant parameters during folliculogenesis in Egyptian buffalo. Anim. Reprod. Sci. 2014, 151, 131-136.

20. Megahed, G. A.; Anwar, M. M.; Wasfy, S. I.; Hammadeh, M. E. Influence of heat stress on the cortisol and oxidant-antioxidants balance during oestrous phase in buffalo-cows (Bubalus bubalis): thermo-protective role of antioxidant treatment. Reprod. Domest. Anim. 2008, 43, 672-677.

21. Paula, F. F. Heat stress induced alteration in bovine oocytes: functional and cellular aspects. Anim. Reprod. 2012, 9, 395-403.

22. Sordillo, L. M. Selenium-dependent regulation of oxidative stress and immunity in periparturient dairy cattle. Veterinary Medicine International. 2013, http://dx.doi.org/10.1155/2013/154045

23. Bassols, A.; Turk, R.; Roncada, P. A proteomics perspective: from animal welfare to food safety. Curr. Protein. Pept. Sc. 2014, 15, 156-168.

24. Neilson, K. A.; Ali, N. A.; Muralidharan, S.; Mirzaei, M.; Mariani, M.; Assadourian, 
G.; Lee, A.; van Sluyter, S. C.; Haynes, P. A. Less label, more free: Approaches in label-free quantitative mass spectrometry. Proteomics. 2011, 11, 535-553.

25. Nahnsen, S.; Bielow, C.; Reinert, K.; Kohlbacher, O. Tools for label-free peptide quantification. Mol. Cell. Proteomics. 2013, 12, 549-556.

26. Peterson, A. C.; Russell, J. D.; Bailey, D. J.; Westphall, M. S. Parallel reaction monitoring for high resolution and high mass accuracy quantitative, targeted proteomics. Mol. Cell. Proteomics. 2012, 11, 1475-1488.

27. Sweredoski, M. J.; Moradian, A.; Raedle, M.; Franco, C.; Hess, S. High resolution parallel reaction monitoring with electron transfer dissociation for middle-down proteomics. Anal. Chem. 2015, 87, 8360-8366.

28. Liu, L.; Wang, A.; Chen, J. Blood-based amyloid and tau biomarker tests for alzheimerâs disease. Neuroscience \& Biomedical Engineering. 2016, 4.

29. Gu, Z. B.; Li, L.; Tang, S. Q.; Liu, C. B.; Fu, X. H.; Shi, Z. X.; Mao, H. M. Metabolomics reveals that crossbred dairy buffaloes are more thermotolerant than Holstein cows under chronic heat stress. J. Agr. Food. Chem. 2018, DOI: $\underline{10.1021 / \text { acs.jafc. } 8 \mathrm{~b} 02862}$

30. Kim, W. S.; Lee, J. S.; Jeon, S. W.; Peng, D. Q.; Kim, Y. S.; Bae, M. H.; Jo, Y. H.; Lee, H. G. Correlation between blood, physiological and behavioral parameters in beef calves under heat stress. Asian. Austral. J. Anim Sci. 2018, 31, 919-925.

31. https://www.uniprot.org/uniprot/P69905

32. Zerounian, N. R.; Linder, M. C. Effects of copper and ceruloplasmin on iron 
transport in the caco 2 cell intestinal model. J. Nutr. Biochem. 2002, 13, 138-148.

33. Chang, Y. Z.; Qian, Z. M.; Du, J. R.; Zhu, L.; Xu, Y.; Li, L.Z.; Wang, C.Y.; Wang, Q.; Ge, X.H.; Ho, K.P.; Niu, L.; Ke, Y. Ceruloplasmin expression and its role in iron transport in c6 cells. Neurochem. Int. 2017, 50, 726-733.

34. Pisoschi, A.M.; Pop, A. The role of antioxidants in the chemistry of oxidative stress: a review. Eur. J. Med. Chem. 2015, 97, 55-74.

35. Rhoads, M. L.; Rhoads, R. P.; VanBaale, M. J.; Collier, R. J.; Sanders, S. R.; Weber, W. J.; Crooker, B. A.; Baumgard, L. H. Effects of heat stress and plane of nutrition on lactating Holstein cows: I. Production, metabolism, and aspects of circulating somatotropin. J. Dairy. Sci. 2009, 92, 1986-1997.

36. Bobek, S.; Sechman, A.; Wieczorek, E.; Wronska-Fortuna, D.; Koziec, K.; Niezgoda, J. Responses of heat stressed chickens to exogenous reverse triiodothyronine (rT3). Transboundary \& Emerging Diseases. 1996, 43, 521.

37. Koch, F.; Lamp, O.; Eslamizad, M.; Weitzel, J.; Kuhla, B. Metabolic response to heat stress in late-pregnant and early lactation dairy cows: implications to livermuscle crosstalk. Plos. One. 2016, 11, e0160912.

38. Yang, L. The function of hydrogen peroxide as signal molecules-the feedback regulation of hydrogen peroxide on respiratory burst in human np. Science Technology \& Engineering. 2002.

39. Adachi, M.; Liu, Y. H.; Fujii, K.; Calderwood, S. K.; Nakai, A.; Imai, K.; Shinomura, Y. Oxidative stress impairs the heat stress response and delays unfolded protein 
recovery, Plos. One. 2009, 4, e7719.

40. Kho, C. W.; Lee, P. Y.; Bae, K. H.; Kang, S.; Cho, S.; Lee, D. H.; Sun, C. H.; Yi, G. S.; Park, B. C.; Park, S. G. Gpx3-dependent responses against oxidative stress in Saccharomyces cerevisiae. J. Microbiol. Biotechnol. 2018, 18, 270-82.

41. Brigelius-Flohe, R. Tissue-specific functions of individual glutathione peroxidases. Free. Radic. Biol. Med. 1999, 27, 951-965.

42. Pan, L.; Bu, D. P.; Wang, J. Q.; Cheng, J. B.; Sun, X. Z.; Zhou, L. Y.; Qin, J. J.; Zhang, X. K.; Yuan, Y. M. Effects of Radix Bupleuri extract supplementation on lactation performance and rumen fermentation in heat-stressed lactating Holstein cows. Anim. Feed. Sci. Tech. 2014, 187, 1-8.

43. Akbarian, A.; Golian, A.; Kermanshahi, H.; De, S. S.; Michiels, J. Antioxidant enzyme activities, plasma hormone levels and serum metabolites of finishing broiler chickens reared under high ambient temperature and fed lemon and orange peel extracts and curcuma xanthorrhiza essential oil. J. Anim. Physiol. An. N. 2015, $99,150-162$.

44. Hu, Y.; Cai, M. C.; Wang, L.; Lin, T.; Wu, B.; Zhang, J. H.; Zuo, F. Y. The serum biochemical indexes and miRNA expression in cattle under heat stress and their correlation analysis. Acta Veterinaria at Zootechnica Sinica. 2016, 47, 1840-1847.

45. Cheng, J. B.; Fan, C.Y.; Sun, X. Z.; Wang, J. Q.; Zheng, N.; Zhang, X. K.; Qin, J. J.; Wang, X. M. Effects of bupleurum, extract on blood metabolism, antioxidant status and immune function in heat-stressed dairy cows. J. Integr. Agr. 2018, 17, 657-663. 
46. Guo, J.; Gao, S.; Quan, S.; Zhang, Y.; Bu, D.; Wang, J. Blood amino acids profile responding to heat stress in dairy cows. Asian. Austral. J. Anim. Sci. 2018, 31, 4753.

47. Zhang, J. X.; Wang, R.; Xi, J.; Shen, L.; Zhu, A. Y.; Qi, Q.; Wang, Q. Y.; Zhang, L. J., Wang, F. C.; Lü, H. Z.; Hu, J. G. Morroniside protects SK-N-SH human neuroblastoma cells against $\mathrm{H}_{2} \mathrm{O}_{2}$-induced damage. Int. J. Mol. Med. 2017, 39, 603-612.

48. Zhang, F. J.; Weng, X. G.; Wang, J. F.; Zhou, D.; Zhang, W.; Zhai, C. C.; Hou, Y. X.; Zhu, Y. H. Effects of temperature-humidity index and chromium supplementation on antioxidant capacity, heat shock protein 72 , and cytokine responses of lactating cows. J. Anim. Sci. 2014, 92, 3026-3034.

49. Tomasinsig, L.; De Conti, G.; Skerlavaj, B.; Piccinini, R.; Mazzilli, M.; D’Este, F.; Tossi, A.; Zanetti, M. Broad-spectrum activity against bacterial mastitis pathogens and activation of mammary epithelial cells support a protective role of neutrophil cathelicidins in bovine mastitis. Infect. Immun. 2010, 78, 1781-1788.

50. Whelehan, C. J.; Barry-Reidy, A.; Meade, K. G.; Eckersall, P. D.; Chapwanya, A.; Narciandi, F.; Lloyd, A. T.; O’Farrelly, C. Characterisation and expression profile of the bovine cathelicidin gene repertoire in mammary tissue. BMC Genomics. 2014, $15,128-128$.

51. Kozłowska, E.; Wysokiński, A.; Brzezińska-Błaszczyk, E. Serum levels of peptide cathelicidin 11-37 in elderly patients with depression. Psychiat. Res. 2017, 255, 156-160.

52. Young-Speirs, M.; Drouin, D.; Cavalcante, P. A.; Barkema, H. W.; Cobo, E. R. 
Host defense cathelicidins in cattle: types, production, bioactive functions and potential therapeutic and diagnostic applications. Int. J. Antimicrob. Ag. 2018, 51, 813-821.

53. Radek, K. A.; Elias, P. M.; Taupenot, L.; Mahata, S. K.; O’Connor, D. T.; Gallo, R. L. Neuroendocrine nicotinic receptor activation increases susceptibility to bacterial infections by suppressing antimicrobial peptide production. Cell. Host. Microbe. 2010, 7, 277-289.

54. Sheeba, V.; Arunachalam, P.; Swarnalatha, K. Correlation of hemoglobin with creatinine clearance, antioxidant status, lipid peroxidation and ceruloplasmin in patients with chronic kidney disease. Inter. J. Res. Med. Sci. 2016, 4, 4487-4492.

55. Young-Speirs, M.; Drouin, D.; Cavalcante, P. A.; Barkema, H. W.; Cobo, E. R. Host defense cathelicidins in cattle: types, production, bioactive functions and potential therapeutic and diagnostic applications. Int. J. Antimicrob. Ag. 2018, 51, 813-821.

56. McNamara, T. C.; Keen, J. T.; Simmons, G. H.; Alexander, L. M.; Wong, B. J. Endothelial nitric oxide synthase mediates the nitric oxide component of reflex cutaneous vasodilatation during dynamic exercise in humans. J. Physiol. 2014, 592, 5317-5326

57. Koga, A.; Ishikawa, N.; Tajima, A.; Homma, H.; Kanai, Y.; Chikamune, T. Characteristics of Physiological Responses and Blood Constituents in Relation to Seasonal Changes of the Environment in Buffaloes Compared with Cattle. Japan. J. Trop. Agr. 1991, 35, 283-288.

58. Gomeza, J.; Shannon, H.; Kostenis, E.; Felder, C.; Zhang, L.; Brodkin, J.; Grinbeng, 
A.; Sheng, H.; Wess, J. Pronounced pharmacologic deficits in $\mathrm{m} 2$ muscarinic acetylcholine receptor knockout mice. Proceedings of the National Academy of Sciences of the United States of America. 1999, 96, 1692-1697.

59. Kumar, S. Glutamic acid as a precursor of acetylcholine synthesis in rat brain in vivo. Observations on the compartmentalization. Brain Research. 1971, 33, 578580.

60. Main, P. A.; Angley, M. T.; O'Doherty, C. E.; Thomas, P.; Fenech, M. The potential role of the antioxidant and detoxification properties of glutathione in autism spectrum disorders: a systematic review and meta-analysis. Nutr. Metab. 2012, 9, 35 .

61. Xu, X.; Leng, J. Y.; Gao, F.; Zhao, Z. A.; Deng, W. B.; Liang, X. H.; Zhang, Y. J.; Zhang, Z. R.; Li, M.; Sha, A. G.; Yang, Z. M. Differential expression and antioxidant function of glutathione peroxidase 3 in mouse uterus during decidualization. FEBS Letters. 2014, 588, 1580-1589.

62. Wilson, N. E.; Stricker, E. M. Thermal homeostasis in pregnant rats during heat stress. Journal of Comparative and Physiological Psychology. 1979, 93, 585-594.

63. Horowitz, M.; Meiri, U. Altered responsiveness to parasympathetic activation of submaxillary salivary gland in the heat-acclimated rat. Comp. Biochem. Physiol. A. Comp. Physiol. 1985, 80, 57-60

64. GonzálezAlonso, J.; Calbet, J. A. Reductions in systemic and skeletal muscle blood flow and oxygen delivery limit maximal aerobic capacity in humans. Circulation. 
2003, 107, 824-830.

65. Pizzuti, C.; Rombo, S. E. Algorithms and tools for protein-protein interaction networks clustering, with a special focus on population-based stochastic methods. Bioinformatics. 2014, 30, 1343-1352.

66. Osaki, S.; Johnson, D. A.; Frieden, E. The possible significance of the ferrous oxidase activity of ceruloplasmin in normal human serum. J. Bio. Chem. 1966, $241,2746-2751$

67. Fosset, C.; McGaw, B. A.; Abramovich, D.; Mcardle, H. J. Interrelations between ceruloplasmin and Fe status during human pregnancy. Biol. Trace. Elem. Res. 2004, 98, 1.

68. Tetik, V.A.; Harman, E.; Bozok, Ç. V.; Kayıkçıoğlu, M.; Vardarl, E.; Zengi, A.; Şahin, A. K.; Eroğlu, Z. Polymorphisms of lipid metabolism enzyme-coding genes in patients with diabetic dyslipidemia. Anatol. J. Cardiol. 2017, 17, 313-321.

69. Cemek, M.; Caksen, H.; Bayiroğlu, F.; Cemek, F.; Dede, S. Oxidative stress and enzymic-non-enzymic antioxidant responses in children with acute pneumonia. Cell Biochemistry \& Function. 2010, 24, 269-273.

70 . Sreedhar, R.; Arumugam, S.; Thandavarayan, R. A.; Giridharan, V. V.; Karuppagounder, V.; Pitchaimani, V.; Afrin, R.; Miyashita, S.; Nomoto, M.; Harima, M.; Gurusamy, N.; Suzuki, K.; Watanabe, K. Myocardial 14-3-3ๆ protein protects against mitochondria mediated apoptosis. Cell. Signal. 2015, 27, 770-776.

71. Collin, A.; Lebreton, Y.; Fillaut, M.; Vincent, A.; Thomas, F.; Herpin, P. Effects of exposure to high temperature and feeding level on regional blood flow and 
oxidative capacity of tissues in piglets. Exp. Physiol. 2010, 86, 83-91.

72. Bain, A. R.; Morrison, S. A.; Ainslie, P. N. Cerebral oxygenation and hyperthermia. Front. Physiol. 2014, 5, 92. doi: 10.3389/fphys.2014.00092.

73. Rubsamen, K.; Hales, J. R. S. Circulatory adjustment of heat-stressed livestock, in Stress physiology in livestock. Basic principles, 1, edited by M.K. Yousef. Boca Raton, Florida: CRC. Press. 1985, 143-154.

74. Ogoh, S.; Sato, K.; Okazaki, K.; Miyamoto, T.; Hirasawa, A.; Morimoto, K.; Shibasaki, M. Blood flow distribution during heat stress: cerebral and systemic blood flow. J. Cerebr. Blood. F. Met. 2013, 33, 1915-1920.

75. Pearce, S. C.; Mani, V.; Boddicker, R. L.; Johnson, J. S.; Weber, T. E.; Ross, J. W.; Rhoads, R. P.; Baumgard, L. H.; Gabler, N. K. Heat stress reduces intestinal barrier integrity and favors intestinal glucose transport in growing pigs. Plos One. 2013, 8, e 70215 .

76. Takahashi, M. Heat stress on reproductive function and fertility in mammals. Reprod. Med. Biol. 2012, 11, 37-47

77. Lublin, A.; Wolfenson, D. Lactation and pregnancy effects on blood flow to mammary and reproductive systems in heat stressed rabbits. Comp. Biochem. Physiol. A. Physiol. 1996, 115, 277-285.

78. Elseddig, H. The effect of open poultry houses design on physiological performance of layer hens. (2010). University of Khartoum, Master degree.

79. Habeeb, A. A. M. The role of insulin in improving productivity of heat stressed farm 
animals with different techniques, Zagazig, Egypt: Ph.D. Thesis, Faculty of Agriculture, Zagazig University (1987).

80. Transport of oxygen and carbon dioxide in blood and tissue fluids. In: A.C. Guyton, J.E. Hall. Textbook of Medical Physiology. 11th ed. Philadelphia: Elsevier. 2006, 503-513.

81. Srikandakumar, A.; Johnson, E.H.; Mahgoub, O. Effect of heat stress on respiratory rate, rectal temperature and blood chemistry in omani and australian merino sheep. Small. Ruminant. Res. 2013, 49, 193-198.

82. Mohanty, J. G.; Nagababu, E.; Rifkind, J. M. Red blood cell oxidative stress impairs oxygen delivery and induces red blood cell aging. Front. Physiol. 2014, 5, 84.

83. Alam, M. M.; Hashem, M. A.; Rahman, M. M.; Hossain, M. M.; Haque, M. R.; Sobhan, Z.; Islam, M.S. Effect of heat stress on behavior, physiological and blood parameters of goat. Progressive. Agriculture. 2013, 22, 37-45.

84. Rana, M. S.; Hashem, M. A.; Sakib, M. N.; Kumar, A. Effect of heat stress on blood parameters in indigenous sheep. Journal of the Bangladesh Agricultural University. 2014, 12, 91-94.

85. Waltz, X.; Baillot, M.; Connes, P.; Bocage, B.; Renaudeau, D. Effects of hydration level and heat stress on thermoregulatory responses, hematological and blood rheological properties in growing pigs. Plos One. 2014, 9, e102537-e102537.

86. Qiang, J.; Bao, W. J.; Tao, F. Y.; He, J.; Li, X. H.; Xu, P.; Sun, L. Y. The expression profiles of mirna-mrna of early response in genetically improved farmed tilapia 
(oreochromis niloticus) liver by acute heat stress. Sci. Rep. 2017, 7. DOI:10.1038/s41598-017-09264-4

87. Srikandakumar, A.; Johnson, E.H. Effect of heat stress on milk production, rectal temperature, respiratory rate and blood chemistry in Holstein, Jersey and Australian Milking Zebu cows. Trop. Animal. Health. Prod. 2004, 36, 685-692.

88. Silva, R.G.; da Costa M.J.; Sobrinho, A.G. Influence of hot environments on some blood variables of sheep. Int. J. Biometeorol. 1992, 36, 223-225.

89. Tucker, C. B.; Rogers, A. R.; Schütz, K. E. Effect of solar radiation on dairy cattlebehaviour: use of shade and body temperature in a pasture-based system. Appl. Anim. Behav. Sci. 2008, 109, 141-154.

90. Brijesh, Y.; Vijay, P.; Sarvajeet, Y.; Yajuvendra, S.; Vinod, K.; Rajneesh, S. Effect of misting and wallowing cooling systems on milk yield, blood and physiological variables during heat stress in lactating murrah buffalo. J. Anim. Sci. Technol. 2018, 58, 2. DOI: $10.1186 / \mathrm{s} 40781-015-0082-0$

91. Sivakumar, A. V. N.; Singh, G.; Varshney, V. P. Antioxidants supplementation on acid base balance during heat stress in goats. Asian. Austral. J. Anim. Sci. 2000, $23,1462-1468$.

92. Xin, W. U.; Li, Z. Y.; Jia, A. F.; Su, H.G.; Hu, C.H.; Zhang, M.H.; Feng, J.H. Effects of high ambient temperature on lipid metabolism in finishing pigs. J. Integr. Agr. 2016, 15, 391-396.

93. Ricartjané, D.; Cejudomartín, P.; Peinadoonsurbe, J.; Lópeztejero, M. D.; Llobera, 
M. Changes in lipoprotein lipase modulate tissue energy supply during stress. J. Appl. Physiol. 2005, 99, 1343-1351.

94 Sturm, R.; Sheynkman, G.; Booth, C.; Smith, L. M.; Pedersen, J. A.; Li, L. Absolute quantification of prion protein (90-231) using stable isotope-labeled chymotryptic peptide standards in a LC-MRM AQUA workflow. J. Am. Soc. Mass Spectrom. 2012, 23, 1522-1533.

95. Larsen, T. S.; Lagercrantz, H.; Riemersma, R. A.; Blix, A. S. Seasonal changes in blood lipids, adrenaline, noradrenaline, glucose and insulin in norwegian reindeer. Acta. Physiol. 1984, 124, 53-59.

96) Kouba, M.; Hermier, D.; Dividich, J. L. Influence of a high ambient temperature on lipid metabolism in the growing pig. J. Anim. Sci. 2001, 79, 81-87.

97. Qu, H.; Donkin, S. S.; Ajuwon, K. M. Heat stress enhances adipogenic differentiation of subcutaneous fat depot-derived porcine stromovascular cells. J. Anim. Sci. 2015, 93, 3832-3842.

98) Mayer, M. L.; Hancock, R. E. Cathelicidins link the endocrine and immune systems. Cell. Host. Microbe. 2010, 7, 257-259.

99. Fuquay, J. W.; Zook, A. B.; Daniel, J. W.; Brown, W. H.; Poe, W. E. Modifications in free stall housing for dairy cows during summer. J. Dairy. Sci. 1979, 62, 566577.

100. West, J. W. Effects of heat-stress on production in dairy cattle: a review. J. Dairy. Sci. 2003, 86, 2131-2144. 
101. Wisniewski, J. R.; Zougman, A.; Nagaraj, N.; Mann, M. Universal sample preparation method for proteome analysis. Nat. Methods. 2009, 6, 359-362.

102. Cox, J.; Mann, M. MaxQuant enables high peptide identification rates, individualized p.p.b.-range mass accuracies and proteome-wide protein quantification. Nat. Biotechnol. 2008, 26, 1367-1372.

103. Cox, J.; Neuhauser, N.; Michalski, A.; Scheltema, R. A.; Olsen, J. V.; Mann, M. Andromeda: a peptide search engine integrated into the maxquant environment. J. Proteome. Res. 2011, 10, 1794-1805.

104. Cox, J.; Hein, M. Y.; Luber, C. A.; Paron, I.; Nagaraj, N.; Mann, M. Accurate proteome-wide label-free quantification by delayed normalization and maximal peptide ratio extraction, termed maxlfq. Mol. Cell. Proteomics. 2014, 13, 25132526.

105 . Saldanha, A. J. Java Treeview-extensible visualization of microarray data. Bioinformatics. 2004, 20, 3246-3248.

106. MacLean, B.; Tomazela, D. M.; Shulman, N.; Chambers, M.; Finney, G. L.; Frewen, B.; Kern, R.; Tabb, D. L.; Liebler, D. C.; MacCoss, M. J. Skyline: an open source document editor for creating and analyzing targeted proteomics experiments. Bioinformatics. 2010, 26, 966-968.

107. Lin, M. M.; Fang, J. B.; Qi, X. J.; Li, Y. K.; Chen, J. Y.; Sun, L. M.; Zhong, Y. P. iTRAQ-based quantitative proteomic analysis reveals alterations in the metabolism of actinidia arguta. Sci. Rep. 2017, 7. 
108. Quevillon, E.; Silventoinen, V.; Pillai, S.; Harte, N.; Mulder, N.; Apweiler, R.; Lopez, R. Interproscan: protein domains identifier. Nucleic. Acids. Res. 2005, 33, 116-120.

109. Ashburner, M.; Ball, C. A.; Blake, J. A.; Botstein, D.; Butler, H.; Cherry, J. M.; Davis, A. P .; Dolinski, K.; Dwight, S. S.; Eppig, J. T.; Harris, M. A.; Hill, D. P.; Issel-Tarver, L.; Kasarskis, A.; Lewis, S.; Matese, J. C.; Richardson, J. E.; Ringwald, M.; Rubin, G. M.; Sherlock, G. Gene ontology: tool for the unification of biology. The Gene Ontology Consortium. Nat. Genet. 2000, 25, 25-29.

110. Götz, S.; Garcíagómez, J. M.; Terol, J.; Williams, T. D.; Nagaraj, S. H.; Nueda, M. J.; Robles, M.; Talón, M.; Dopazo, J.; Conesa, A. High-throughput functional annotation and data mining with the blast2go suite. Nucleic. Acids. Res. 2008, 36, 3420-3435.

111. Kanehisa, M.; Goto, S.; Sato, Y.; Furumichi, M.; Tanabe, M. KEGG for integration and interpretation of large-scale molecular data sets. Nucleic. Acids. Res. 2012, 40, $109-114$.

Table 1. Proteins Differentially Abundant in Heat-stressed Buffalo as Compared 
to Normal-temperature Buffalo, as Indicated by Label-free Quantitation

\begin{tabular}{|c|c|c|c|c|}
\hline Protein ID & Protein symbol & Protein name & Fold change & $\mathrm{P}$ \\
\hline Q9TSN7 & HBA1 & Hemoglobin subunit alpha1 & 3.76 & 0.036 \\
\hline L8I5R0 & $\mathrm{CP}$ & Ceruloplasmin, & 1.50 & 0.024 \\
\hline A0A0A7V3V9 & CAMP (LL-37) & Cathelicidin-2, CATHL2 & 1.84 & 0.026 \\
\hline D2U6Z5 & $\mathrm{CP}$ & Ceruloplasmin & 1.58 & 0.035 \\
\hline P63103 & YWHAZ & YWHAZ & 0.35 & 0.001 \\
\hline P37141 & GPX3 & Glutathione peroxidase 3 & 0.35 & 0.006 \\
\hline K9MNT8 & RETN & Resistin & 0.47 & 0.022 \\
\hline Q2KII3 & HAVCR1 & $\begin{array}{l}\text { Hepatitis A virus cellular receptor } 1 \mathrm{~N} \text { - } \\
\text { terminal domain containing protein }\end{array}$ & 0.44 & 0.030 \\
\hline P62261 & YWHAE & Protein epsilon & 0.52 & 0.001 \\
\hline G5E5V0 & CPN1 & $\begin{array}{l}\text { Carboxypeptidase } \mathrm{N} \text { catalytic chain } \\
\text { precursor }\end{array}$ & 0.63 & 0.007 \\
\hline E1ACW2 & LPL & Lipoprotein lipase & 0.59 & 0.010 \\
\hline A7Z057 & YWHAG & Protein gamma & 0.51 & 0.017 \\
\hline L8I9P7 & CD14 & Monocyte differentiation antigen & 0.65 & 0.020 \\
\hline L8I6N0 & CHST4 & $\begin{array}{l}\text { Glycosylation-dependent cell adhesion } \\
\text { molecule } 1 \text {, }\end{array}$ & 0.59 & 0.022 \\
\hline L8IDW3 & THBS4 & Thrombospondin-4 & 0.57 & 0.033 \\
\hline L8IZ21 & SERPINF1 & Pigment epithelium-derived factor & 0.65 & 0.034 \\
\hline L8HYL8 & PLA1A & Phospholipase A1 member A & 0.56 & 0.045 \\
\hline
\end{tabular}


Table 2. Gene Ontology (GO) Analysis of the Proteins Differentially Abundant in

Heat-stressed Buffalo as Compared to Normal-temperature Buffalo

\begin{tabular}{|c|c|c|}
\hline GO_ID & GO term & Proteins associated \\
\hline GO:0004602 & Glutathione peroxidase activity & P37141 \\
\hline GO:0016787 & Hydrolase activity & E1ACW2, G5E5V0, L8HYL8 \\
\hline GO:0019825 & Oxygen binding & Q9TSN7 \\
\hline \multirow[t]{2}{*}{ GO:0016491 } & Oxidoreductase activity & L8I5R0, P63103, P62261, \\
\hline & & A7Z057, P37141, D2U6Z5 \\
\hline GO:0030235 & Nitric-oxide synthase regulator activity & L8IAK0 \\
\hline GO:0051082 & Unfolded protein binding & L8IAK0 \\
\hline GO:0031072 & Heat shock protein binding & L8IAK0 \\
\hline GO:0004497 & Monooxygenase activity & P63103, P62261, A7Z057 \\
\hline GO:0005179 & Hormone activity & K9MNT8 \\
\hline GO:0016616 & Oxidoreductase activity & L8I5R0 \\
\hline GO:0016298 & Lipase activity & E1ACW2, L8HYL8 \\
\hline GO:0004322 & Ferroxidase activity & L8I5R0, D2U6Z5 \\
\hline GO:0004806 & Triglyceride lipase activity & E1ACW2 \\
\hline GO:0031625 & Ubiquitin protein ligase binding & P63103, P62261 \\
\hline
\end{tabular}



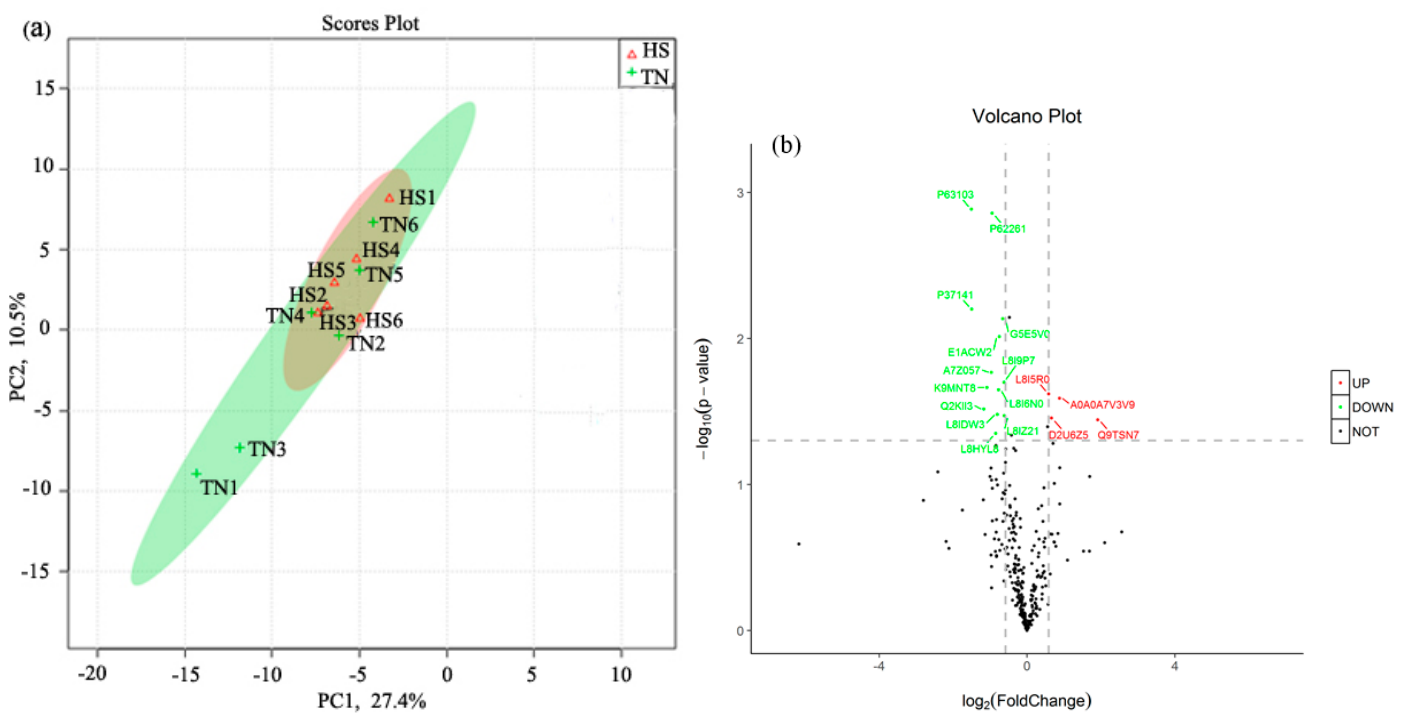

Figure 1. 




Figure 2. 

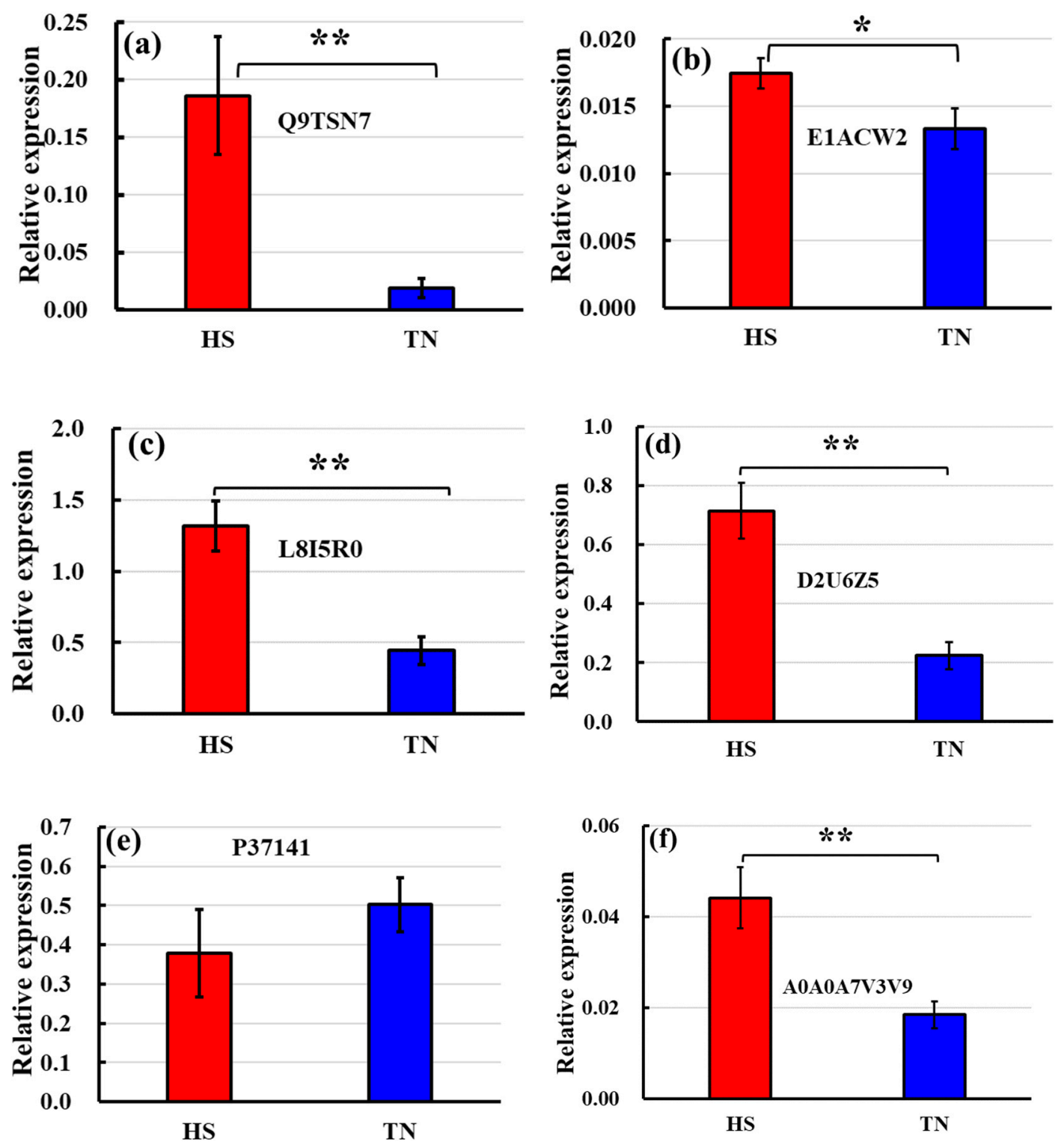

Figure 3. 


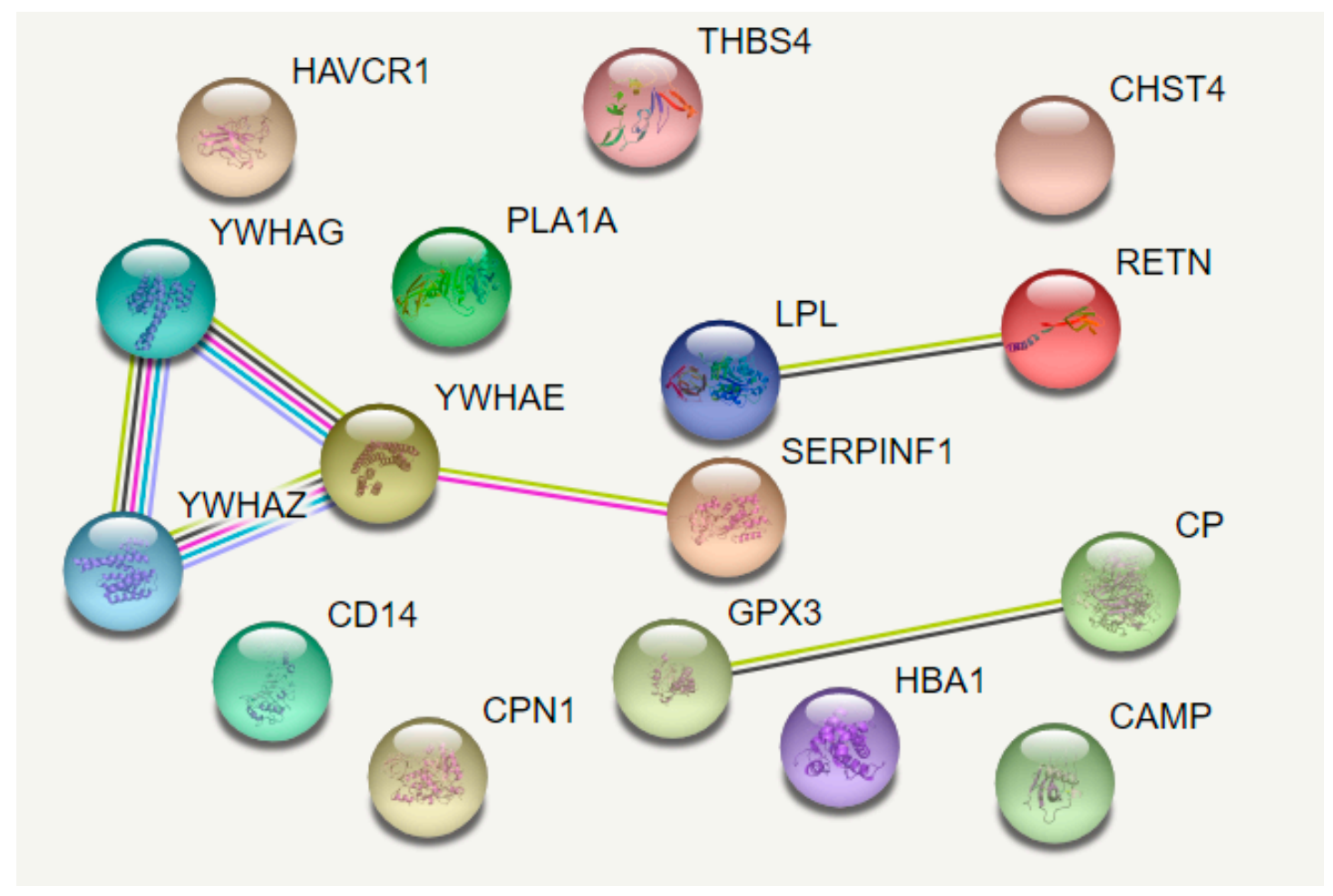

Figure 4. 


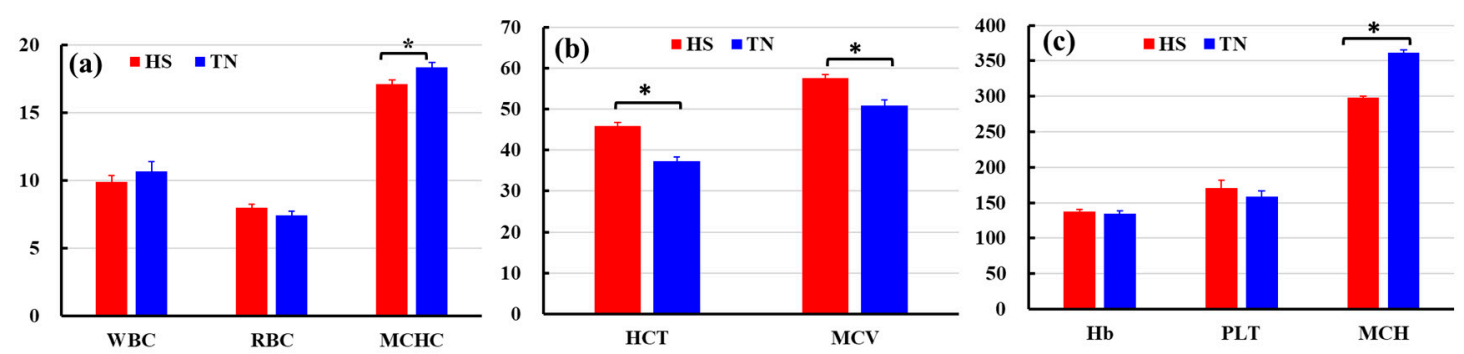

Figure 5. 


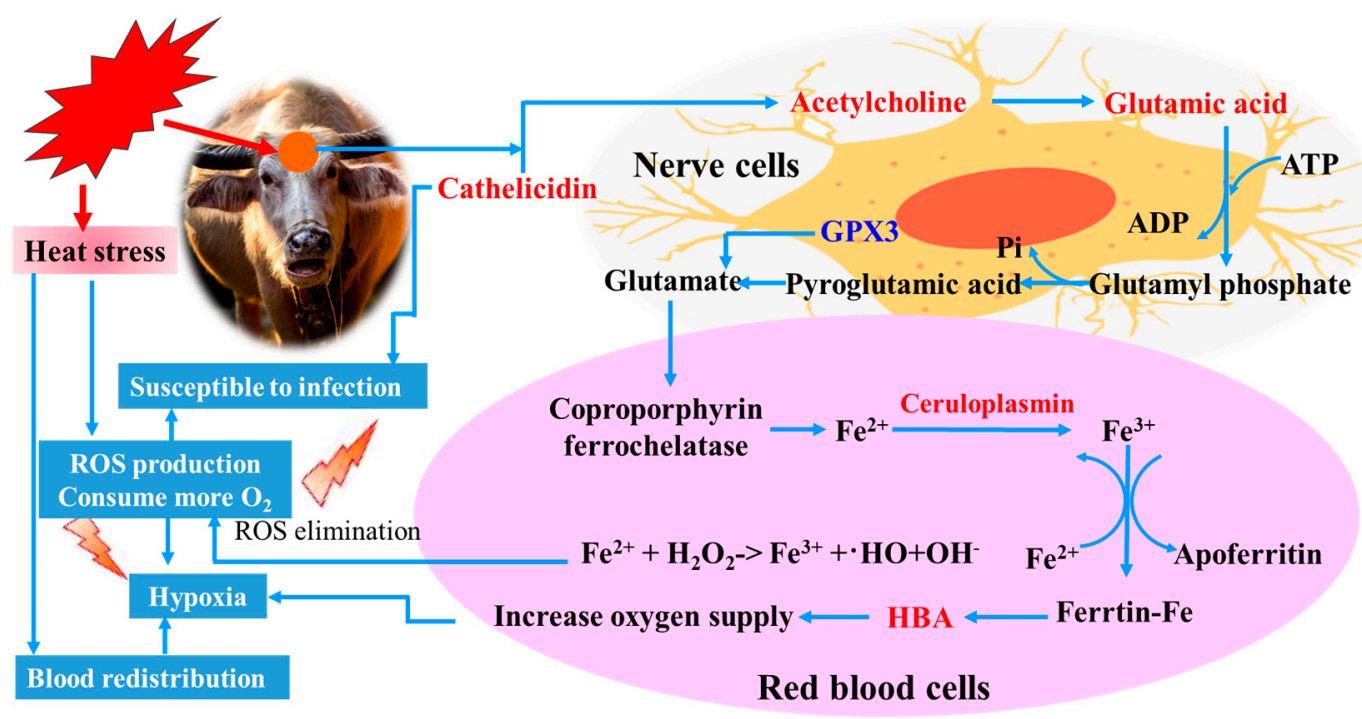

Figure 6. 